\title{
How the Firm can Build Customers' Loyalty to Its Website
}

\author{
Mohamed Ali Barakat Ali \\ Assistant Professor of Marketing \\ Faculty of Business \\ Ain Shams University-Egypt
}

\begin{abstract}
This study aims to explain how customer loyalty to a firm's website can be formed. The designed questionnaire was distributed to 600 e-buyers in Egypt. The collected data from 490 valid questionnaires were analyzed using spss. 16 and amos.18. The results indicated that e-service quality dimensions are website information, website reliability, website ease of use, and website security. The results revealed that there is a significant and positive relationship between perceived e-service quality dimensions and e-customer satisfaction, there is a significant and positive relationship between e-customer satisfaction and e-customer loyalty and there is a significant and positive relationship between perceived ease of use of the website and e-customer loyalty.
\end{abstract}

Keywords: E-Service Quality-E-Customer Satisfaction-E-Customer loyalty.

\section{Introduction}

Internet is considered one of the main tools which firms use for marketing and selling their products and it is considered one of the methods which customers use for shopping and purchasing products. (Bart, et al.,2005) mentioned that the internet has become important marketing mean for firms.(Vos, et al.,2014) stated that nowadays, due to the growth of the use of e-services, the internet is considered a convenient mean to shop and buy.This study aims to answer the following questions:

Q1:What are the main dimensions of e-service quality in the Egyptian context?

Q2: Doe-service quality dimensions affect e-customer satisfaction significantly?

Q3:Does e-customer satisfaction impact e-customer loyalty significantly?

Q4:Do e-service quality dimensions influence e-customer loyalty directly and indirectly?

\section{Literature Review}

\section{E-Service Quality and its dimensions}

(Boyer, et al.,2002) defined e-service as the delivery of all interactive services on the internet using advanced information technologies.(Zeithaml, et al.,2002) defined e-service quality as a degree to which certain website facilitates customers' shopping, purchasing products, and delivering products to customers efficiently and effectively. (Parasuraman, et al.,2005) defined e-service quality as the extent to which a website facilitates efficient and effective shopping, purchasing, and delivery.(Santos,2003,Parasuraman,et al.,2005,Bauer,et al.,2006,Liao,et al.,2011) defined eservice quality as a customer's overall judgment on the quality of the services that are delivered through the internet.(Zeithaml, et al.,2000) concluded that the customers evaluate websites according to five criteria: information availability and content, ease of use, privacy and security, graphic style, and fulfillment of purpose.(Barnes and Vidgen,2001) built Web Qual scale which consists of three main dimensions; they are website design quality, website information quality, and website service quality.

(Yoo and Donthu's,2001) established a Site Qual scale which consists of four dimensions; they are ease of use, design, operating speed, and security.(Zeithaml, et al.,2002) built another e-service scale which consists of five main criteria for evaluating e-service quality; they are information availability and content, ease of use, privacy and security, design, and reliability.(Wolfinbarger and Gilly,2003) established the E-Tail Q scale which consists of four dimensions; they are design, reliability, security, and service.(Santos,2003) suggested another scale for measuring e-service quality which consists of ten dimensions; they are ease of use, shape, communication, structure, content, reliability, efficiency, support, communication, and security.(Song and Zinkhan,2003) found that factors affecting customers' evaluation of website quality are ease of searching for a website, ease of access to information, ease of purchasing, entertainment, and design. (Ribbink, et al.,2004) suggested that there are five dimensions of e-service quality; they are ease of use, 
design, customization, responsiveness, and assurance.(Parasuraman, et al.,2005) suggested the E-S-Qual scale which consists of four dimensions; they are efficiency, the fulfillment of customer's needs, system availability, and privacy.

(Parasuraman, et al.,2005) suggested the E-Rec-S-Qual scale which consists of three dimensions; they are responsiveness, compensation, and communication.(Bressolles,2006) developed Net Qual scale which consists of five basic dimensions; they are ease of use, information, reliability, privacy, and interactive ability.(Santouridis, et al.,2009) mentioned that there are six dimensions of e-service quality; they are assurance, quality of information, responsiveness, assistance, empathy, and reliability.(Bult,2016) concluded that there are four basic characteristics that customers use to evaluate e-service quality; they are the design of a website, the fulfillment of customer's needs, customer service, and security and privacy.(Collier and Bienstock,2006) defined website ease of use as website usability that represents customers' ability to get information and finish the transactions with the lowest effort. Website usability includes ease of communication, ease of entering the website, ease of searching for information and downloading them, ease of submitting purchasing request, paying the price, or canceling the request. (Cheng, et al.,2012) defined perceived ease of use as the degree to which the person believes that usage of a certain website will be easy and doesn't need any effort.(Reibstein,2002) suggested that perceived ease of use involves ease of browsing and ease of getting information. (Van Reil,et al.,2004) suggested that the website design dimension includes content, organization, and structure.

(Barnes and Vidgerr,2001;Wolfinbarger and Gilly,2003) indicated that information system quality consists of system quality that represents program quality and information quality that includes convenience, adequacy, completeness, brevity, accuracy, recentness, understandability, reliability, and accessibility.(Cristobal, et al.,2007) defined website reliability as the ability of an e-commerce firm to keep its promises toward its customers. Website reliability involves keeping selling conditions, inventory availability, and delivering in the determined timing. (Ribbink, et al.,2004) suggested that website security includes security of transactions, customer trust in e-commerce firms, and achieving privacy for customers. (Bart, et al.,2005) defined online privacy as protection from publishing customers' information via the internet.(Parasuraman, et al.,2005) defined website security and privacy as protecting the personal data of the customer and explicit and implicit agreement on not selling or disseminating information collected from customers.

(Kerkhof and Van Noort,2010) stated that purchasing online is perceived as risky.(Miyazaki and Fernandez,2001) mentioned that the key strategy of online marketers is to decrease customer risk and increase customer trust in online exchanges by displaying security and privacy policy on their websites.(Parasuraman, et al.,2005) found that the risk of misusing customer's information makes many people don't purchase online and e-commerce firm tends to demonstrate its privacy policy to its customers.(Fench and O'cass,2001) mentioned that the causes of a positive customer attitude towards online purchasing are the securityof electronic transactions, available shopping, and feeling of the importance of online purchasing.(Katos,2012) defined e-customer trust as a non -opportunistic behavior of seller, customer's receiving of the products which he/she expects, and customer satisfaction with dealing with unknown online sellers.(Sahney, et al.,2013) defined e-customer trust as a customer's feeling of trustworthiness and security towards electronic transactions.(katos,2012) defined e-perceived risk as an online seller's misuse of customers' personal information required to complete e-transactions.(Check and Ho,2016) concluded that there is a significant relationship between e-customer trust and e-customer purchasing intentions.

\section{E-Customer Satisfaction}

(Oliver, 1980) mentioned that customer satisfaction refers to meeting the customer's expectations about the product. (Kotler,1991) stated that satisfaction reflects a post-purchase evaluation of product quality given pre-purchase expectations.(Oliver,1993) stated that if the perceived performance matches or exceeds the customers' expectations, they will be satisfied, and if it doesn't, they will be dissatisfied.(Szymanski and Hise's,2000) defined satisfaction as a cumulative effect of a set of discrete experiences with the service provider over a period of time.(Severt,2002) defined satisfaction as a global evaluation of all aspects that make up the customer relationship with the service.(Szymanski and Henard,2001) defined e-satisfaction as the customers' judgment on their internet experiences compared to their experiences with the traditional way of dealing with customers.(Anderson and Srinivasan,2003; Kim and Stoe,2004; Boyer and Hut,2006) definede-customer satisfaction asa continuous customer's evaluation of primary purchasing experience with an e-commerce firm.(Yi and La,2004) defined accumulated e-customer satisfaction as an accumulated and pleasant fulfillment through multiple customer experiences with an e-commerce firm.

\section{E-Customer Loyalty}

Marketing scholars used many definitions of e-customer loyalty. (Edvardsson, et al.,2000) defined loyalty as a customer's intention to purchase from the same organization again.(Srinivasan, et al.,2002) defined e-customer loyalty as a customer's favorable attitude towards the e-retailer that results in repeat buying behavior. (Anderson and Srinivasan,2003) defined e-customer loyalty as the tendency of customers to use a specific website continuously, visit it 142 
frequently and spend a long time during the visit.(Anderson and Srinivasan,2003) defined e-customer loyalty as a customer's favorable attitude toward an electronic business resulting in repeat buying behavior.

(Flavian, et al.,2006) defined online loyalty as a customer's intention to buy from a certain website without change to another website. (Cyr,2008) defined that e-customer loyalty as a customer's intention to revisit a website and purchasing from it in the future. (Ha, et al.,2010) defined e-customer repurchasing intentions as a consumer's willingness to repurchase product (s) offered from a specific website.(Chang, et al.,2014) defined e-customer repurchasing intentions as a probability of customer's usage of the same website(s) to purchase the same product(s). (Ball, et al.,2004) mentioned that there are two main dimensions for measuring customer loyalty: attitudinal loyalty and behavioral loyalty.(Bowen and Shoemaker,1998) mentioned that attitudinal loyalty refers to customer's repurchase intentions.(Zeithaml, et al.,1996) mentioned that behavioral loyalty refers to customer's repurchase behavior.

\section{E-Service Quality and E-Customer Satisfaction}

(Zeithmal, et al.,2000) concluded that there is an association between e-service quality-related variables such as efficiency, reliability, and security, and e-customer satisfaction.(Smith,2003) found that customers' satisfaction with eservices quality is affected by ease of transactions, perceived enjoyment, the security of customers' information, comfort, and time-saving. (Cristobal, et al.,2007) found that positive customer perceptions of e-service quality will result in satisfaction with the e-service of the website. (Sahadev and Purani,2008) found that there is a significant relationship between components of e-service quality and e-customer satisfaction.(Fassnacht and Rose,2007; Herington and Weaven,2009) suggested that perceived e-service quality affects significantly and positively e-customer satisfaction.(Kassim and Abdullah, 2010; Cheng, et al.,2012) suggested that ease of use, design, responsiveness, and security can affect positively e-customer satisfaction. (Ali,2016) found that usability, performance, security, and privacy affect significantly customer experience with website browsing which affects significantly e-customer satisfaction and e-customer purchasing intentions.(Kemeny, et al.,2016) concluded that efficiency and responsiveness affect significantly and positively e-customer satisfaction which affects significantly and positively e-customer word of mouth.(Yi and La,2004) indicated that e-service quality dimensions are predictors of e-customer satisfaction which is affected by the benefits gained from using the retailer's website.(Vos, et al., 2014) concluded that e-service quality dimensions have significant and positive impacts on e-customer satisfaction. According to the previous discussion, the first hypothesis was suggested as follows:

H1:There is a significant and positive relationship between e-service quality dimensions and e-customer satisfaction.H1 involves the following sub-hypotheses:

H1-a: There is a significant and positive relationship between website ease of use and e-customer satisfaction.

H1-b: There is a significant and positive relationship between website information and e-customer satisfaction.

H1-c: There is a significant and positive relationship between website reliability and e-customer satisfaction.

H1-d: There is a significant and positive relationship between website security and e-customer satisfaction.

\section{E-Customer Satisfaction and E-Customer Loyalty}

(Zeithaml, et al.,1996;Bloemer, et al.,1998;Cronin,et al.,2000;Nguyen and Leblanc,2002;Kassim and Abdullah,2010; Baumann, et al.,2011; Amin, et al.,2013; Thaichan, et al.,2014) concluded that customer satisfaction has a positive impact on customer loyalty. (Harris and Goode,2004) concluded that there is a significant relationship between ecustomer satisfaction and e-customer loyalty.(Chiou and Shen,2006) stated that e-loyalty is a consequence of satisfaction with the e-service provider.(Casalo, et al.,2008) stated that e-customer satisfaction is a key antecedent of customer e-loyalty.(Chang, et al.,2014) concluded that there is a positive relationship between e-customer satisfaction and e-customer repurchasing intentions.(Anderson and Srinivasan,2003; Hsu, et al.,2013; Sreeram, et al.,2017) found that e-customer satisfaction affects significantly and positively e-customer loyalty.(Wong and Zhou,2006; Gounaris, et al.,2010;Levy,2014) mentioned that customers who are satisfied with internet banking are more likely to engage in a consistent relationship with internet banking in the future and demonstrate a more loyal behavior.(Wang and Kim, 2019) indicated that e-customer satisfaction affects significantly e-customer loyalty and this effect is greater for female customers than male customers. According to the previous discussion, the second hypothesis was suggested as follows:

$\mathrm{H} 2$ : There is a significant and positive relationship between e-customer satisfaction and e-customer loyalty.

\section{E-Service Quality and E-Customer Loyalty}

(Zeithmal, et al.,1996) concluded that there is a significant relationship between superior e-service quality dimensions and behavioral intentions of customers like greater loyalty.(Chiu, et al.,2009) concluded that perceived website ease of use has a significant and positive effect on e-customer loyalty.(Carlson and O'Cass,2010) found that perceived e- 
service quality dimensions (ease of use; utility; enjoyment) affects significantly and positively customers' behavioral intentions (website's revisit intentions; the e-positive word of mouth;recommending others to revisit a website)

(Wolfinbarger and Gilly,2002) mentioned that four main factors help in building e-customer loyalty; these factors are website design, website ease of use; fulfillment of users' needs, and website security. (Gera,2011) indicated that eservice quality affects significantly perceived value which in turn affects significantly e-customer loyalty. (Vos, et al.,2014) found that e-service quality dimensions have significant and positive influences on e-customer loyalty.(Amin,2016) indicated that e-service quality significantly affects e-customer satisfaction which consequently leads to e-customer loyalty.(Lee and Lin,2005) emphasized that the perception of e-service quality is important for both attracting new potential customers and retaining current customers. According to the previous discussion, the third hypothesis was suggested as follows:

H3:There is a significant and positive relationship between e-service quality dimensions and e-customer loyalty. H3 involves the following sub-hypotheses:

H1-a: There is a significant and positive relationship between website ease of use and e-customer loyalty. H1-b: There is a significant and positive relationship between website information and e-customer loyalty. H1-c: There is a significant and positive relationship between website reliability and e-customer loyalty. H1-d: There is a significant and positive relationship between website security and e-customer loyalty.

\section{Mediating effect of e-customer satisfaction on the relationship between e-service quality and e-customer loyalty}

(Jeon and Jeong,2017) concluded that the website's service quality is the main predictor of e-customer satisfaction which leads to e-customer repurchasing intentions.(Al-dweeri, et al.,2018) found that e-customer satisfaction mediates the relationship between e-service quality and e-customer loyalty.(Krauss, et al.,2005) indicated that a firm's competitiveness can be reinforced by applying e-marketing and increasing e-customer loyalty. According to the previous discussion, the fourth hypothesis was suggested as follows:

H4: E-customer satisfaction mediates the relationship between e-service quality dimensions and e-customer loyalty.H4 involves the following sub-hypotheses:

H4-a:E-customer satisfaction mediates the relationship between website ease of use and e-customer loyalty.

H4-b: E-customer satisfaction mediates the relationship between website information and e-customer loyalty.

H4-c:E-customer satisfaction mediates the relationship between website reliability and e-customer loyalty.

H4-d:E-customer satisfaction mediates the relationship between website security and e-customer loyalty.

\section{Proposed model}

Figure(1) shows the proposed model which includes variables namely e-service quality dimensions, e-customer satisfaction, and e-customer loyalty.

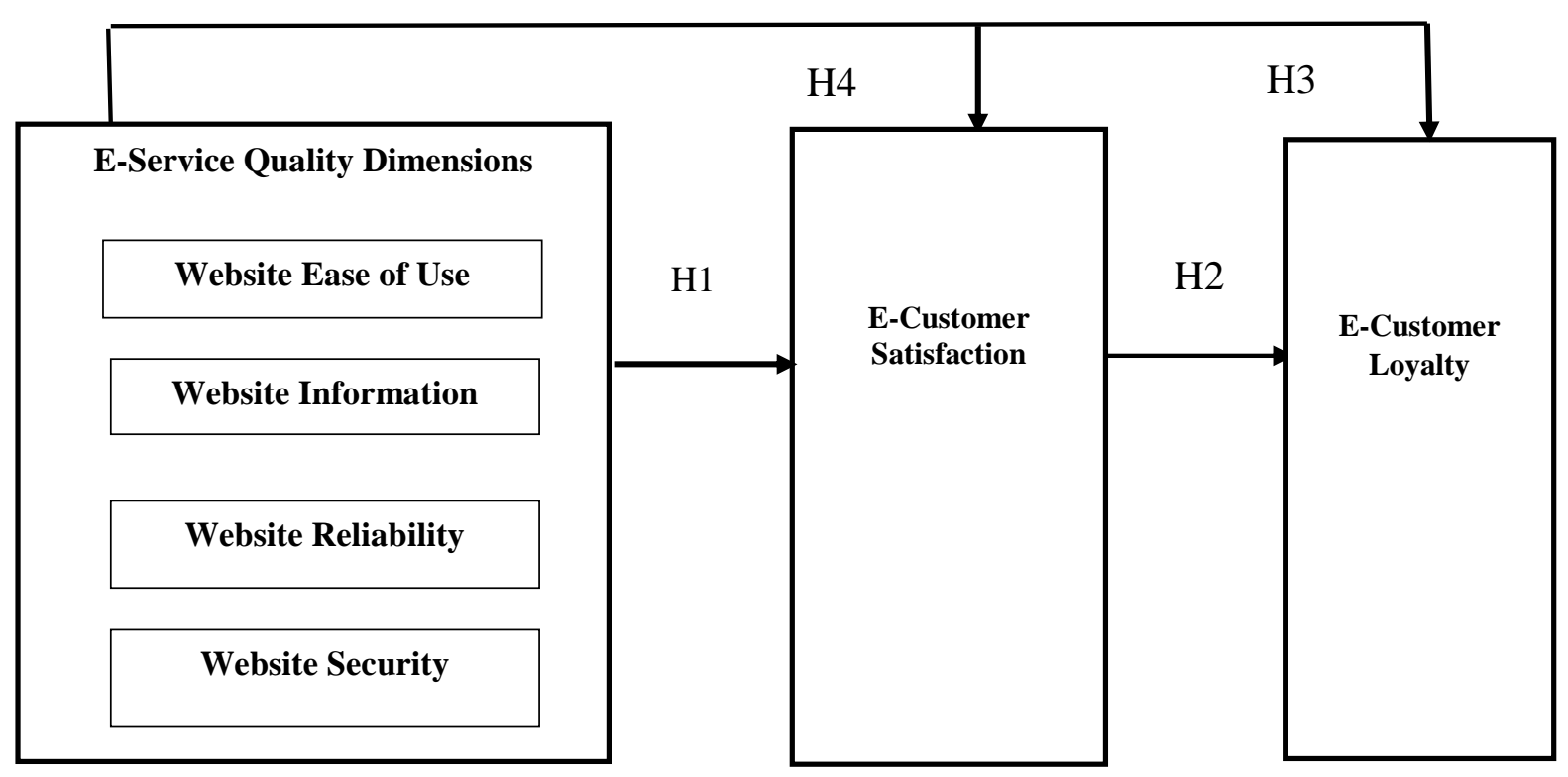




\section{Figure (1): Proposed Model}

\section{Methods}

\section{Sampling and data collection}

The research sample size was 600e-buyers in Egypt. The sample size was calculated by using a sample size calculator according to the following assumptions: population size $=1,520,000$ Egyptian e-buyers, confidence level $=95 \%$, and margin of error $= \pm 4 \%$. The number of respondents was 490 e-buyers. The response rate was $81.67 \%$.

The questionnaire used for collecting responses of users was designed and distributed online. Collected data were analyzed using Spss.16 and Amos.18.

\section{Measures}

The researcher used a 5-item scale which was developed by (Bressolles, et al.,2014) for measuring website ease of use. The researcher used a 5-item scale which was developed by (Bressolles and Durrieu, 2010) for measuring website information. The researcher used a 4-item scale which was developed by (Cristobal, et al.,2007 and Bressolles, et al.,2015) for measuring website reliability. The researcher used a 4-item scale which was developed by (Bressolles and Durrieu, 2010 and Bressolles, et al.,2015) for measuring website security. The researcher used a 5-item scale which was developed by (Oliver,1980 and Ribbink, et al.,2004) for measuring e-customer satisfaction. The researcher used a 4-item scale which was developed by (Zeithmal, et al.,1996) for measuring e-customer loyalty. Table (1) shows the evaluation of research measures.Itincludes the reliability analysis using Cronbach's alpha $(\alpha)$ and composite reliability $(\mathrm{CR})$, testing construct validity using factor loadings $(\lambda)$, and testing convergent validity using average variance extracted (AVE).

Table (1): Measurement Model Evaluation

\begin{tabular}{|c|c|c|c|c|}
\hline Construct & $\begin{array}{c}\text { Factor loadings } \\
(\lambda)\end{array}$ & $\begin{array}{c}\text { Cronbach's Alpha } \\
(\alpha)\end{array}$ & $\begin{array}{c}\text { Composite } \\
\text { Reliability (CR) }\end{array}$ & $\begin{array}{l}\text { Average Variance } \\
\text { Extracted (AVE) }\end{array}$ \\
\hline $\begin{array}{l}\text { Website Ease of } \\
\text { Use }\end{array}$ & & & & \\
\hline EOU1 & 0.866 & \multirow{4}{*}{0.890} & \multirow{4}{*}{0.888} & \multirow{4}{*}{0.714} \\
\hline EOU2 & 0.809 & & & \\
\hline EOU3 & 0.852 & & & \\
\hline EOU4 & 0.852 & & & \\
\hline $\begin{array}{l}\text { Website } \\
\text { Information }\end{array}$ & & & & \\
\hline WI1 & 0.702 & \multirow{5}{*}{0.838} & \multirow{5}{*}{0.838} & \multirow{5}{*}{0.511} \\
\hline WI2 & 0.797 & & & \\
\hline WI3 & 0.741 & & & \\
\hline WI4 & 0.613 & & & \\
\hline WI5 & 0.708 & & & \\
\hline $\begin{array}{l}\text { Website } \\
\text { Reliability }\end{array}$ & & & & \\
\hline WR1 & 0.836 & \multirow{3}{*}{0.850} & \multirow{3}{*}{0.840} & \multirow{3}{*}{0.637} \\
\hline WR2 & 0.810 & & & \\
\hline WR3 & 0.745 & & & \\
\hline $\begin{array}{l}\text { Website } \\
\text { Security }\end{array}$ & & & & \\
\hline WS1 & 0.677 & \multirow{4}{*}{0.854} & \multirow{4}{*}{0.850} & \multirow{4}{*}{0.587} \\
\hline WS2 & 0.792 & & & \\
\hline WS3 & 0.798 & & & \\
\hline WS4 & 0.790 & & & \\
\hline \multicolumn{5}{|l|}{$\begin{array}{l}\text { E-Customer } \\
\text { Satisfaction }\end{array}$} \\
\hline ES1 & 0.895 & \multirow{4}{*}{0.925} & \multirow{4}{*}{0.947} & \multirow{4}{*}{0.817} \\
\hline ES2 & 0.915 & & & \\
\hline ES3 & 0.934 & & & \\
\hline ES4 & 0.871 & & & \\
\hline \multicolumn{5}{|l|}{$\begin{array}{l}\text { E-Customer } \\
\text { Loyalty }\end{array}$} \\
\hline EL1 & 0.823 & \multirow{4}{*}{0.857} & \multirow{4}{*}{0.904} & \multirow{4}{*}{0.701} \\
\hline EL2 & 0.828 & & & \\
\hline EL3 & 0.858 & & & \\
\hline EL4 & 0.840 & & & \\
\hline
\end{tabular}

Note: EOU=website ease of use, WI=website information, WR=website reliability, WS=website security, ES=ecustomer satisfaction, and EL=e-customer loyalty. 
Table (1) shows that all constructs exhibited acceptable composite reliability values exceeding the minimum limit of 0.7 suggested by (Bagozzi,1994). Table (1) shows that AVE (average variance extracted) for all constructs was greater than 0.5 confirming internal consistency and convergent validity (Fornell and Larcker,1981).

Exploratory factor analysis using principal component analysis extraction method and varimax rotation method was used on 24 items which represent dimensions of e-service quality, e-customer satisfaction, and e-customer loyalty. The Bartlett test of sphericity was significant $(\chi 2=7890.917, \mathrm{df}=276$, sig $=0.000)$ and the Kaiser-Meyer-Olkin measure of sampling adequacy $(\mathrm{KMO}=0.892)$ was greater than 0.5 which shows that the use of factor analysis was appropriate. 24 items in the questionnaire were reduced to six factors. Factor loading for each scale item maintained the minimum standard of 0.5.These results are shown in table (1).The resultant factor structure explained $72.94 \%$ of high communalities across the scale components. Eigenvalues for all six factors were greater than 1 (website ease of use $=3.288$, website information $=3.123$, website reliability $=3.050$, website security $=2.972$,e-customer satisfaction $=$ 2.602,e-customer loyalty $=2.471$ ).

To test the construct validity of measures of research a confirmatory factor was computed also. Fit indices of the CFA model for e-service quality, e-customer satisfaction and e-customer loyalty are as follows: $\chi 2 / \mathrm{DF}=3.265, \mathrm{P}=0.000$, $\mathrm{RMR}=0.038, \mathrm{RMSEA}=0.082, \mathrm{GFI}=0.945, \mathrm{AGFI}=0.890, \mathrm{NFI}=0.946, \mathrm{RFI}=0.908, \mathrm{IFI}=0.958, \mathrm{TLI}=0.928, \mathrm{CFI}=$ 0.958. $\chi 2 / \mathrm{DF} \leq 3, \mathrm{RMR}$ and RMSEA $\leq 0.08$ and GFI, AGFI, NFI, RFI, IFI, TLI, and CFI $\geq 0.90$. Fit values are well within the acceptable range. These values indicated that there is a good fit between estimated values and actual data (Bryne, 2010). All correlations are significant at 0.001. This result is presented in Table (2). Figure (2) illustrates the CFA model for measuring dimensions of e-service quality,e-customer satisfaction, and e-customer loyalty.

Table .2 Confirmatory factor analysis for measuring dimensions of e-service quality, e-customer satisfaction, and e-customer loyalty.

\begin{tabular}{|l|c|c|c|c|c|}
\hline \multicolumn{1}{|c|}{ Path } & $\begin{array}{c}\text { Standardized } \\
\text { Regression Weights }\end{array}$ & $\begin{array}{c}\text { Un-Standardized } \\
\text { Regression Weights }\end{array}$ & $\begin{array}{c}\text { Standard } \\
\text { Error }\end{array}$ & $\begin{array}{c}\text { Critical } \\
\text { Ratio }\end{array}$ & Probability \\
\hline F1 $\rightarrow$ EOU1 & 0.865 & 1.000 & - & - & - \\
\hline F1 $\rightarrow$ EOU4 & 0.847 & 0.946 & 0.065 & 14.521 & $* * *$ \\
\hline F2 $\rightarrow$ WI1 & 0.862 & 1.000 & - & - & - \\
\hline F2 $\rightarrow$ WI2 & 0.854 & 0.907 & 0.050 & 18.142 & $* * *$ \\
\hline F3 $\rightarrow$ WR1 & 0.867 & 1.000 & - & - & - \\
\hline F3 $\rightarrow$ WR2 & 0.836 & 0.976 & 0.054 & 18.049 & $* * *$ \\
\hline F4 $\rightarrow$ WS1 & 0.773 & 1.000 & - & - & - \\
\hline F4 $\rightarrow$ WS3 & 0.742 & 0.777 & 0.056 & 13.927 & $* * *$ \\
\hline F5 $\rightarrow$ ES3 & 0.821 & 1.000 & - & - & - \\
\hline F5 $\rightarrow$ ES2 & 0.935 & 0.900 & 0.043 & 21.174 & $* * *$ \\
\hline F6 $\rightarrow$ EL4 & 0.734 & 1.000 & - & - & - \\
\hline F6 $\rightarrow$ EL1 & 0.826 & 0.880 & 0.072 & 12.228 & $* * *$ \\
\hline
\end{tabular}

Note. $* * *: \mathrm{P}<0.001$. 


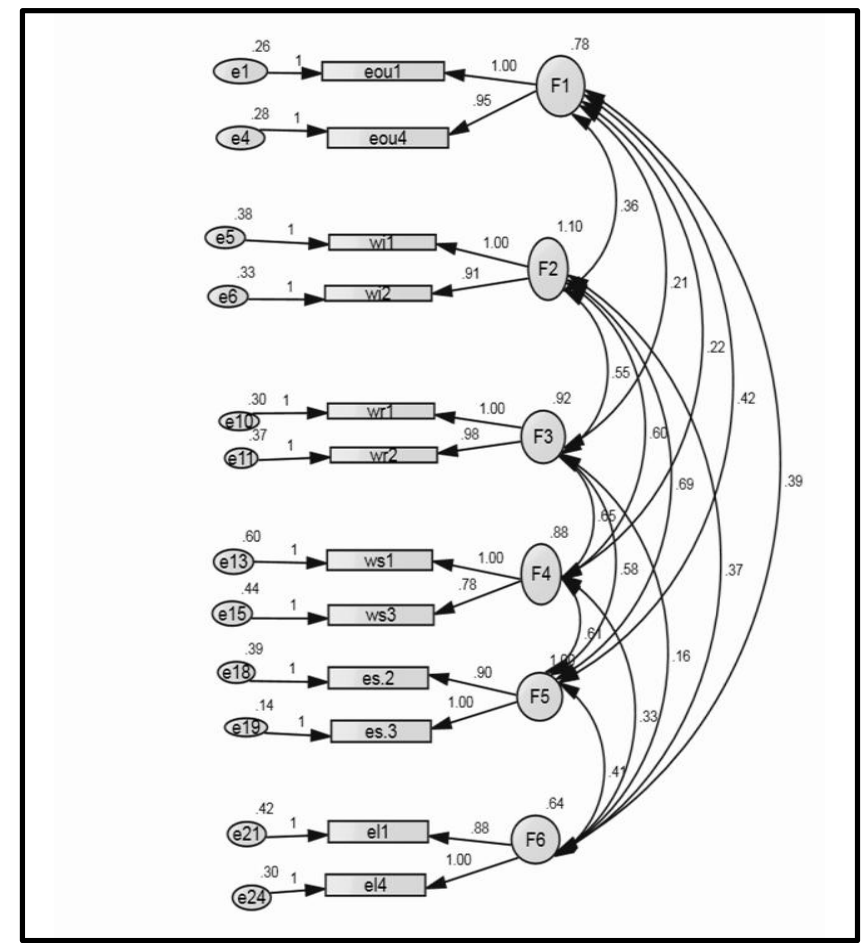

Figure .2 CFA model for measuring dimensions of e-service quality, e-customer satisfaction, and e-customer loyalty

Table (3) shows that the square root of AVE for each construct was greater than the absolute value of the correlation between each pair of constructs confirming discriminant validity.

Table.3 The discriminant validity test

\begin{tabular}{|l|l|l|l|l|l|l|l|}
\hline Construct & $\begin{array}{l}\text { Square Root } \\
\text { Of AVE }\end{array}$ & EOU & WI & WR & WS & ES & EL \\
\hline EOU & 0.845 & 1 & & & & & \\
\hline WI & 0.715 & $0.405^{* *}$ & 1 & & & & \\
\hline WR & 0.798 & $0.259^{* *}$ & $0.527^{* *}$ & 1 & & & \\
\hline WS & 0.766 & $0.295^{* *}$ & $0.541^{* *}$ & $0.562^{* *}$ & 1 & & \\
\hline ES & 0.904 & $0.255^{* *}$ & $0.632^{* *}$ & $0.603^{* *}$ & $0.564^{* *}$ & 1 & \\
\hline EL & 0.837 & $0.425^{* *}$ & $0.381^{* *}$ & $0.249^{* *}$ & $0.378^{* *}$ & $0.444^{* *}$ & 1 \\
\hline
\end{tabular}

Note. ** Correlation is significant at the 0.01 level.

\section{Findings}

The proposed hypotheses in the proposed model $(\mathrm{H} 1-\mathrm{H} 4)$ were tested by using the structural equation modeling technique (SEM) through path analysis. Table (4) shows the results of bath analysis for the research model.

Table .4 Path analyses

Note. $* * *: \mathrm{P}<0.001$.

\begin{tabular}{|l|l|l|l|l|l|}
\hline $\begin{array}{l}\text { Significant } \\
\text { Path }\end{array}$ & $\begin{array}{l}\text { Standardized } \\
\text { Regression } \\
\text { Weight }\end{array}$ & $\begin{array}{l}\text { Unstandardized } \\
\text { Regression } \\
\text { Weight }\end{array}$ & S.E. & $\begin{array}{l}\text { T- } \\
\text { value }\end{array}$ & P. \\
\hline EOU $\rightarrow$ ES & 0.221 & 0.206 & 0.037 & 6.023 & $* * *$ \\
\hline $\mathrm{WI} \rightarrow$ ES & 0.207 & 0.231 & 0.035 & 5.936 & $* * *$ \\
\hline WR $\rightarrow$ ES & 0.270 & 0.282 & 0.039 & 6.973 & $* * *$ \\
\hline WS $\rightarrow$ ES & 0.213 & 0.235 & 0.035 & 6.006 & $* * *$ \\
\hline ES $\rightarrow$ EL & 0.261 & 0.327 & 0.035 & 7.546 & $* * *$ \\
\hline EOU $\rightarrow$ EL & 0.232 & 0.271 & 0.037 & 6.250 & $* * *$ \\
\hline
\end{tabular}


Fit indices of bath analysis for the tested research model are as follows: $\chi 2 / \mathrm{DF}=2.847, \mathrm{P}=0.000$, $\mathrm{RMR}=0.017, \mathrm{RMSEA}=0.061$ GFI=0.994,AGFI=0.960,NFI=0.991,RFI=0.954,IFI=0.994, TLI= 0.970,CFI=0.994.Fit values are well within the acceptable range.These values indicated that there is a good fit between the structural model and data. Figure (3) shows the tested model.Accordingtothe results of the path analysis, all dimensions of e-service quality (ease of use, information, reliability, and security) affect significantly and positively e-customer satisfaction.So,H1 was supported. This result coincides with the results of previous studies.E-customer satisfaction affects significantly and positively e-customer loyalty.So,H2 was supported. This result coincides with the results of previous studies. Website ease of use dimension only affects significantly and positively e-customer loyalty. So,H3 was supported partially. This result coincides with the results of previous studies.E-customer satisfaction mediates the relationship between all e-service quality dimensions and e-customer loyalty. So,H4 was supported. This result coincides with the results of previous studies. Table (5) shows the mediating effect of e-customer satisfaction on the relationship between e-service dimensions and e-customer loyalty. According to regression analysis, all e-service quality dimensions explain $50.9 \%$ of variation in e-customer satisfaction ( $\mathrm{F}=127.593$,Sig=0.000).E-customer satisfaction explains $19.6 \%$ of variation in e-customer loyalty $(\mathrm{F}=119.868, \mathrm{Sig}=0.000)$. Website ease of use dimension explains $16.8 \%$ of variation in e-customer loyalty $(\mathrm{F}=99.957, \mathrm{Sig}=0.000)$.

Table .5Mediating effect of e-customer satisfaction on the relationship between e-service quality dimensions and e-customer loyalty

\begin{tabular}{|l|l|l|l|}
\hline Construct & $\begin{array}{l}\text { Direct } \\
\text { Effect }\end{array}$ & $\begin{array}{l}\text { Indirect } \\
\text { Effect }\end{array}$ & $\begin{array}{l}\text { Total } \\
\text { Effect }\end{array}$ \\
\hline EOU & 0.271 & 0.067 & 0.338 \\
\hline WI & 0.000 & 0.075 & 0.075 \\
\hline WR & 0.000 & 0.092 & 0.092 \\
\hline WS & 0.000 & 0.077 & 0.077 \\
\hline
\end{tabular}

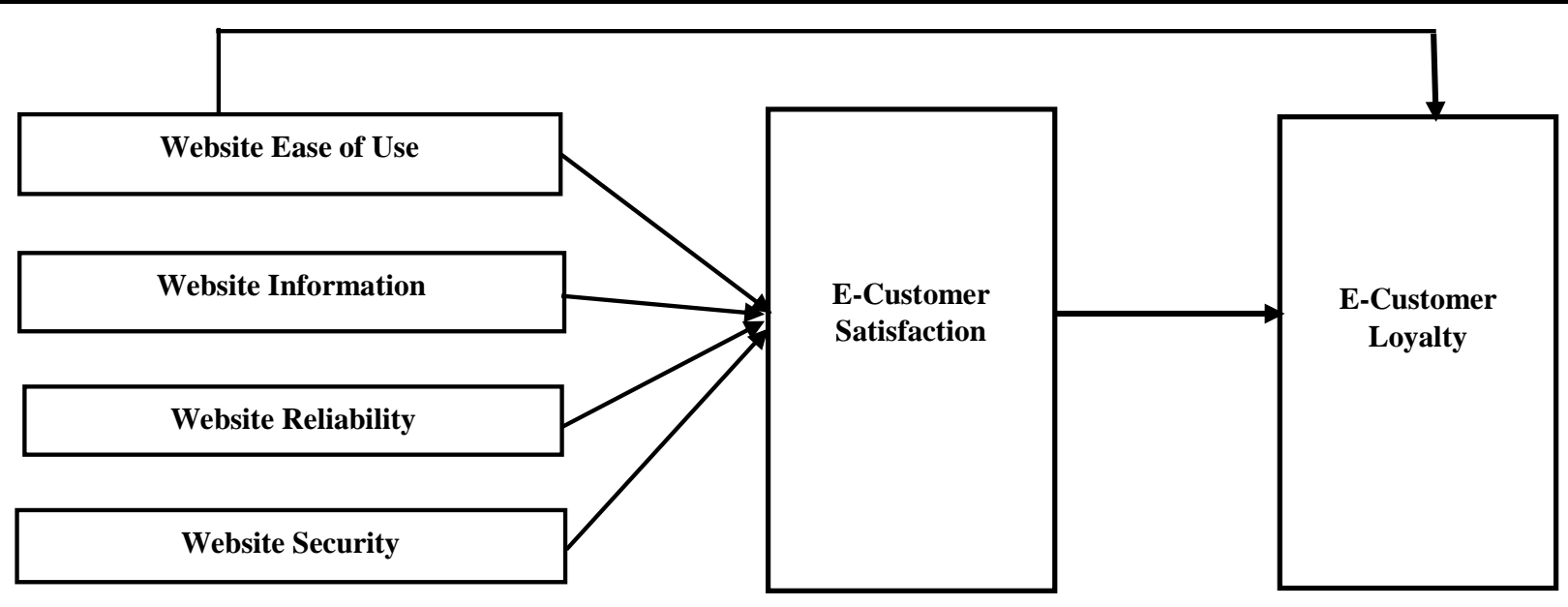

Figure.3 Tested Model

\section{Managerial Implications and recommendations}

E-commerce firms should build high e-customer loyalty. An e-commerce firm can build high customer loyalty to its website by increasing customer satisfaction with its website. E-customer satisfaction can be accomplished by increasing perceived e-service quality dimensions. There are many ways to increase perceived e-service quality. Increasing perceived website information can be achieved by providing the customers with suitable, adequate, detailed, accurate, and recent information about offered products. Increasing perceived website reliability can be achieved by providing the customers with information about inventory availability, methods of delivery, and timing of delivery, and keeping the promises offered to the customers. Increasing perceived website ease of use can be accomplished through the ease of entering the website, ease of browsing and searching for information, and ease of completing transactions. Increasing perceived website security can be done by protecting and securing customers' data and explaining the firm's privacy policy to its customers.

\section{Future Research}


Other topics can be studied in this field such as the impact of using ads on social media on customer buying intentions, customer word of mouth, and customer loyalty.

\section{References:}

Al-deweeri, R.M.; Moreno, A.R.; Montes, F.J.L.; Obeidat, Z. and Al-dwairi, k., (2018),"The Effect Of E-Service Quality ON Jordanian Student's E-Loyalty: An Empirical Study In On-Line Retailing", Industrial Management And Data Systems, Available at www.emeraldinsight.com/0263-5577.htm

Ali, Faizan, (2016)," Website Quality, Perceived Flow,Customer Satisfaction and Purchase Intention", Journal of Hospitality and Tourism Technology, Vol.7, No.2, pp.213-228.

Amin, M., Isa, Z. and Fontaine, R.,(2013),"Islamic Banks: Contrasting the Drivers of Customer Satisfaction on Image, Trust, and Loyalty of Muslim and Non-Muslim Customers in Malaysia", International Journal of Bank Marketing, Vol.31, No.2, pp. 79-97.

Amin, M.,(2016),"Internet Banking Service Quality and Its Implication On E-Customer Satisfaction And E-Customer Loyalty",International Journal Of Bank Marketing,Vol.34,No.3,pp.280-306.

Anderson, R. and Srinivasan, S.,(2003),"E-Satisfaction and E-Loyalty: A Contingency Framework",Psychology and Marketing,Vol.20,No.2,pp.123-138.

Anderson, R.E. and Srinivasan, S.S.,(2003), E-Satisfaction and E-loyalty: A Contingency Framework, Psychology \& Marketing,Vol.20,No. 2,pp.123-138.

Anderson, R.E. and Srinivasan, S.S.,(2003),"E-Satisfaction and E-Loyalty: A Contingency Framework", Psychology and Marketing,Vol.20,No.2,pp.123-138.

Bagozzi, R. P. (1994)."The Effects of Arousal on the Organization of Positive and Negative Affect and Cognitions: Application to Attitude Theory", Structural Equation Modeling, Vol.1,No.3,pp.222-252.

Ball, D., Coelho, P.S. and Machas, A.,(2004),"The Role of Communication and Trust in Explaining Customer Loyalty: An Extension to The ECSI Model", European Journal of Marketing, Vol.38,Nos.9/10,pp.1272-1293.

Barnes, S.J. and Vidgen, R.,(2001),An Evaluation of Cyber Bookshops: The Web Qual Method", International Journal of Electronic Commerce, Vol.6, No.1,pp.11-30.

Bart, Y., Shankar, V., Sultan, F. and Urban, G.L.,(2005),"Are the Drivers and Role of Online Trust the Same for All Websites and Consumers? A Large Scale Exploratory Empirical Study", Journal of Marketing,Vol.69,No.4,pp.133-152.

Bauer, H.H., Falk, T., and Hammerschmidt, M.,(2006),"E Trans Qual: A Transaction Process-Based Approach for Capturing Service Quality in Online Shopping", Journal of Business Research,Vol.59,No.7,pp.866-875.

Baumann, C., Elliott, G. and Hamin, H.,(2011),"Modelling Customer Loyalty in Financial Services: A Hybrid of Formative and Reflective Constructs", International Journal of Bank Marketing,Vol.29,No.3,pp.247-267.

Bloemer, J., De Ruyter, K. and Peeters, P.,(1998),"Investigating Drivers of Bank Loyalty: The Complex Relationship Between Image, Service Quality and Satisfaction ",International Journal of Bank Marketing, Vol.16,No.7,pp.276-286.

Bowen, J.T. and Shoemaker, S.,(1998),"Loyalty: A Strategic Commitment",Cornell Hotel and Restaurant Administration Quarterly, Vol.39,No.1,pp.12-25.

Boyer, K. K., and Hult, G. T. M.,(2006)," Customer Behavioral Intentions For On-Line Purchases: An Examination Of Fulfillment Method and Customer Experience Level", Journal Of Operations Management, Vol.24, No.2, pp.124-147.

Boyer, K.K., Hallowell, R. and Roth, A.V.,(2002),"E-Services: Operations Strategy-A Case Study and A Method for Analyzing Operational Benefits", Journal of Operations Management,Vol.20,No.2,pp.175-188.

Bryne, B. M. (2010). Structural Equation Modeling with Amos: Concepts, Applications, and Programming (2nd ed.). Routledge.

Bult, M., (2016), "E-Service Quality: Development of A Hierarchical Model", Journal of Retailing, Vol.92,No.4,pp.500-517.

Carlson, J., and. O' Cass, A, (2010), Exploring the relationships between e-service quality, satisfaction, attitudes and behaviors in content-driven e-service web sites", Journal of Services Marketing, Vol.24,No.2,pp.112-127.

Casalo, L.V., Flavian, C. and Guinaliu, M.,(2008),"The Role of Satisfaction and Website Usability in Developing Customer Loyalty and Positive Word of Mouth in The E-Banking Services",The International Journal of Bank Marketing, Vol.26, No.6,pp.399-417.

Chang, S. C.; Chou, P. Y.; and Lo, W. C.,(2014),"Evaluation of Satisfaction and Repurchase Intention in Online Food Group-Buying, Using Taiwan As an Example, British Food Journal, Vol.116, No.1, pp. 44-61.

Chek, Y.L. and Ho, J.S.Y.,(2016),"Consumer Electronics E-Tailing: Why The Alliance Of Vendors' E-Service Quality,Trust and Trustworthiness Matters" $3^{\text {rd }}$ Global Conference On Business And Social Science- 
2015,GCBSS-2015,16-17-December 2015,Kualalumpur,Malaysia,Procedia-Social And Behavioral Sciences, pp.804-811.

Cheng, S.; Tsai, M.; Cheng, N., and Chen, K.,(2012), Predicting intention to purchase on group buying website in Taiwan: Virtual community, critical mass, and risk, Online Information Review,Vol.36,No.5,pp.698-712.

Chiou, J. and Shen, C.,(2006),"The Effects of Satisfaction Opportunism Asset Specificity on Consumer's Loyalty Intention Toward Internet Portal Sites", International Journal of Service Industry Management,Vol.17,No.1,pp.7-22.

Chiu,Chao-Min; Chang, Chen-Chi; Cheng, Hsiang-Lan and Fang, Yu-Hui, (2009), "Determinants of customer repurchase intention in online shopping", Online Information Review, Vol.33, No.4, pp .761-784.

Collier,J.E. and Beinstock, C.C.,(2006), "Measuring Service Quality In E-retailing, Journal of Service Research,Vol.8,No.3,pp. 260-275.

Cristobal, E., Flavian, C., and Guinaliu, M.,(2007),"Perceived E-Service Quality (PeSQ): Measurement Validation and Effects on Consumer Satisfaction and Website Loyalty", Managing Service Quality,Vol.17,No.3,pp.317-340.

Cristobal, E.; Flavian, C. and Guinaliu, M.,(2007),"Perceived E-Service Quality (PESQ) measurement Validation and Effects on Consumer Satisfaction and Website Loyalty, Managing Service Quality, Vol.17, No.3, pp.317-340.

Cronin, J. J. Jr, Brady, M.K. and Hult, G.T.M.,(2000),"Assessing The Effects of Quality, Value and Customer Satisfaction on Consumer Behavioral Intentions In-Service Environments", Journal of Retailing,Vol.76,No.2,pp.193-218.

Edvardsson, B., John, M.D., Gustafsson, A. and Strandvik, T.,(2000),"The Effects of Satisfaction and Loyalty on Profits and Growth: Products Versus Services", Total Quality Management,Vol.11,pp.917-927.

Fassnacht, M. and Kose, I.,(2007), "Consequences of Web-Based Service Quality: Uncovering A multi-Faceted Chain of Effects, Journal of Interactive Marketing, Vol.21,No.3,pp.35-54.

Fenech, T. and O'cass, A.,(2001)," Internet Users' Adoption of Website Retailing: User and Product Dimensions", Journal of Product and Brand Management, Vol.10, No.6, pp.361-381.

Flavian, C., Guinaliu, M. and Gurrea, R.,(2006),"The Role Played by Perceived Usability, Satisfaction and Consumer Trust on Website and Loyalty", Information and Management, Vol.43, No.1,pp.1-14.

Fornell, C. and Larcker, D. F., (1981),"Evaluating Structural Equation Models with Unobservable Variables and Measurement Error", Journal of Marketing Research, Vol.18,No.1, 39-80.

Gera, R.,(2011),"Modelling E-Service Quality and Its Consequences in India: An SEM Approach", Journal of Research in Interactive Marketing,Vol.5,No.2/3,pp.203-225.

Gounaris, S., Dimitriadis, S. and Stathakopoulos, V.,(2010),"An Examination of The Effects of Service Quality and Satisfaction on Customers' Behavioral Intentions In E-Shopping", Journal of Services Marketing,Vol.24,No.2,pp.142-156.

Ha, H., Muthaly, S.K., and Akamavi, R. K.,(2010), Alternative Explanations of online Repurchasing Behavioral Intentions: A Comparison Study of Korean and UK. Young Customers, European Journal of Marketing, Vol.44,No.6,pp.874-904.

Harris, L.C. and Goode, M.H.,(2004),"The Four Levels of Loyalty and The Pivotal Role of Trust: A Study of Online Service Dynamics", Journal of Retailing, Vol.89,pp.139-158.

Herington,C. and Weaven, S.,(2009)," E-Retailing by banks: E-service Quality and its importance to customer satisfaction", European Journal of Marketing, Vol.43, No.(9/10), pp.1220-1231.

Hsu, C.; Wu, C. and Chen, M.,(2013), An Empirical analysis Of the Antecedents Of E- Satisfaction And E-Loyalty: Focusing on The Role of Flow and Its Antecedents, Information System E-Business Management, Vol.11,pp.287-311.

Jeon, M.M. and Jeong, M.,(2017),"Customers' Perceived Website Service Quality and Its Effects On E-Loyalty", International Journal of Contemporary Hospitality Management, Vol.29,No.1,pp.438-457.

Kassim, N. and Abdullah, N.A.,(2010),"The Effect of Perceived Service Quality Dimensions on Customer Satisfaction, Trust and Loyalty in E-Commerce Settings: A Cross-Cultural Analysis", Asia Pacific Journal of Marketing and Logistics, Vol.22, No.3,pp.351-371.

Kassim, N. and Abdullah, N.A.,(2010),"The effect of perceived service quality dimensions on customer satisfaction, trust, and loyalty in e-commerce settings: Across cultural analysis, Asia Pacific Journal of Marketing and Logistics, Vol.22, No.3, pp.351-371.

Katos, V.,(2012),"An Integrated Model for Online Transactions: Illuminating the Black Box", Information Management and Computer Security, Vol.20,No.3,pp.184-206.

Kemeny, L.; Simon, J.; Nagy, A. and Szucs, K.,(2016),"Measuring Quality Perception in Electronic Commerce: A Possible Segmentation in Hungarian Market", Industrial Management and Data Systems, Vol.116,No.9,pp.1946-1966. 
Kerkhof, P. and Van Noort, G.,(2010),"Third Party Internet Seals: Reviewing The Effects On Online Consumer Trust", In Lee, I.(Ed),Encyclopedia of E-Business Development and Management In The Global Economy, Information Science Reference,Hershey,PA,pp.701-708.

Kim,S. and Stoe,L.,(2004), Dimensional Hierarchy of Retail Website Quality, Information, and Management, Vol.41,No.5,pp.619-633.

Kotler, P.,(1991),"Marketing Management-Analysis, Planning, Implementation and Control", $7^{\text {th }}$ ed., Prentice-Hall, Englewood Cliffs, NJ.

Krauss, M.; Barwise, P. and Fariey, J.U.,(2005)," The State of Interactive Marketing in Seven Countries: Interactive Marketing Comes of Age", Journal Of Interactive Marketing,Vol.19,No.3,pp.67-80.

Lee, G. and Lin, H.,(2005), Customer perceptions of e-service quality in online shopping, International Journal of Retail and Distribution Management, Vol.33, No.2, pp.161-178.

Levy, S.,(2014),"Does Usage Level of Online Services Matter to Customers' Bank Loyalty?", Journal of Services Marketing,Vol.28,No.4,pp.292-299.

Liao, C.H., Yen, H. R. and Li, E.Y.,(2011),"The Effect of Channel Quality in Consistency on The Association Between E-Service Quality and Customer Relationships", Internet Research,Vol.21,No.4,pp.458-478.

Miyazaki, A.D., and Fernandez, A.,(2001),"Consumer Perceptions of Privacy and Security Risks for Online Shopping", Journal of Consumer Affairs, Vol.35, No.1, pp. 27-44.

Nguyen, N. and Leblanc, G.,(2002),"Contact Personnel, Physical Environment and The Perceived Corporate Image of Intangible Services By New Clients", International Journal of Service Industry Management,Vol.13,No.3,pp.242-262.

Oliver, R.L.,(1980),"A Cognitive Model of The Antecedents and Consequences of Satisfaction Decisions", Journal of Marketing Research,Vol.17,No.4,pp.460-469.

Oliver, R.L.,(1993),"A Conceptual Model of Service Quality and Service Satisfaction: Compatible Goals, Different Concepts", Advances in Services Marketing and Management,Vol.2,No.4,pp.65-85.

Parasuraman, A., Zeithmal, V.A., and Malhotra, A.,(2005),"E-S-Qual: A Multiple-Item Scale for Assessing Electronic Service Quality", Journal of Service Research, Vol.7,No.3,pp.213-233.

Parasuraman, A.; Zeithaml, V. and Malhorta, A.,(2005)," E-S-Qual: A multi -Item Scale for Assessing Electronic Service Quality", Journal of Service Research, Vol.7, No.3, pp.213-233.

Reibstein, D.J.,(2002), What attracts customers to online stores and what keeps them coming back ?, Journal of The Academy of marketing science, Vol.30,No.4,pp.465-473.

Ribbink, D., Van Reil, A.C.R., Liljander, V. and Streukens, S.,(2004),"Comfort Your Online Customer: Quality, Trust and Loyalty on The Internet", Managing Service Quality,Vol.14,No.6,pp.446-456.

Ribbink, D.; Van Reil, AC.R.; Liljander, V. and Streukens, S.,(2004), Comfort your online customer: Quality, Trust and Loyalty on the internet, Managing Service Quality,Vol.14,No.6,pp.446-456.

Sahadev, S. and Purani, K.,(2008),"Modelling the Consequences of E-Service Quality", Marketing, Intelligence \& Planning,Vol.26,No.6,pp.605-620.

Sahney, S.; Ghosh, K.; and Shrivastiva, A.,(2013), "Conceptualizing Consumer Trust in Online Buying Behaviour: An Empirical Inquiry and Model Development in Indian Context", Journal of Asia Business Studies, Vol.7,No.3,pp.278-298.

Santos, J.,(2003),"E-Service Quality: A Model of Virtual Service Quality Dimensions", Managing Service Quality,Vol.13,No.3,pp.233-246.

Santos, J.,(2003), "E-Service Quality: A Model of Virtual Service Quality Dimensions", Managing Service Quality,Vol.13,No.3,pp.233-246.

Santouridis, L., Trivellas, P. and Reklitis, P.,(2009),"Internet Service Quality and Customer Satisfaction: Examining Internet Banking in Greece",Total Quality Management,Vol.20,No.2,pp.223-239.

Seeram, A.; Kesharwani, A. and Desai, S.,(2017),"Factors Affecting Satisfaction and Loyalty in Online Grocery Shopping: An Integrated Model", Journal of Indian Business Research, Vol.9, No.2,pp.107-132.

Severt, E.,(2002),"The Customer's Path to Loyalty: A Partial Test of The Relationships of Prior Experience, Justice and Customer Satisfaction", Doctoral Thesis, Faculty of Virginia, Polytechnic Institute and State University (EEUU),Blackburg, VA.

Smith, A.D.,(2003), "Information Exchanges Associated with Internet Travel Marketplaces", Online Information Review,Vol.28No.4,pp.292-300.

Song, J.H. and Zinkhan, G.M.,(2003), "Features of Website Design,Perceptions of Website Quality and Patronage Behavior, http: //www.acme.org/ PDF files/paper.16 PDF.

Srininvasan, S.S., Anderson, R. and Ponnavolu, K.,(2002),"Customer Loyalty in E-Commerce: An Exploration of Its Antecedents and Consequences", Journal of Retailing,Vol.78,pp.41-50. 
Szymanski, D.M., and Henard, D.H.,(2001),"Customer Satisfaction: A Meta-Analysis of The Empirical Evidence",Journal of The Academy of Marketing Science,Vol.29,No.1,pp.16-35.

Szymanski, D.M., and Hise, R.T.,(2000),"E-Satisfaction: An Initial Examination", Journal of Retailing, Vol.76,No.3,pp.309-322.

Thaichon, P., Lobo, A. and Mitsis, A.,(2014),"An Empirical Model of Home Internet Services Quality in Thailand",Asia Pacific Journal of Marketing and Logistics, Vol.26,No.2,pp.190-210.

Van Reil, A.C.R.; Lemmick, J.; Streukens, S., and Liljander, V.,(2004), "Boost customer loyalty with online support: The Case of Mobile Telecoms Providers", International Journal Of internet marketing and advertising,Vol.1,No.1,pp.4-23.

Vos, A., Marinagi, C., Trivellas, P., Eberhagen, N., Giannakopoulos, G. and Skourlas, C.,(2014),"Electronic Service Quality In Online Shopping and Risk Reduction Strategies", Journal of Systems and Information Technology, Vol.16, No.3, pp.170-186.

Wang, W., and Kim, S.,(2019),"Lady First? The Gender Difference in The Influence of Service Quality on Online Consumer Behavior", Nankai Business Review International, Available at:www. Emerald Insight .com/20408749.htm

Wolfinbarger, M. and Gilly, M,(2002), "Shopping Online for Freedom Control And fun", California Management Review, Vol.43, No.2, pp.34-45.

Wolfinbarger, M. and Gilly, M.,(2003), E-Tail Q: Dimensionlizing, Measuring, and Predicting E-Tail Quality, Journal of Retailing, Vol.79, No.3, pp.183-198.

Wolfinbarger, M.F. and Gilly, M.C.,(2003),"E-Tail Q: Dimensionalizing, Measuring and Predicting Retail Quality", Journal of Retailing, Vol.79,pp.183-198.

Wong, A. and Zhou, L.,(2006),"Determinants and Outcomes of Relationship Quality: A Conceptual Model and Empirical Investigation", Journal of International Consumer Marketing,Vol.18,No.3,pp.81-105.

Yi, Y. and La, S.,(2004), "What Influences the Relationship Between Customer Satisfaction and Repurchase Intentions? Investigating the Effects Of Adjusted Expectations and Customer Loyalty", Psychology \& Marketing,Vol.21,No.5,pp.351-373.

Yoo, J. and Donthu's, (2001), "The Effects of Online Product Presentation on Consumer Responses:Mental Imagery Perspective", Paper Presented At The American Collegiate Retailing Association Annual Meeting, Orland,F.L.,p.1.

Zeithaml V.A., Parasuraman, A., and Malhorta, A.,(2002),"Service Quality Delivery Through Websites: A Critical Review of Extant Knowledge",Journal of The Academy of Marketing Science,Vol.30,No.4,pp.362-375.

Zeithaml, V.A., Berry, L.L. and Parasuraman, A., (1996), "The Behavioral Consequences of Service Quality", Journal of Marketing,Vol.60,No.2,pp.31-46.

Zeithaml, V.A., Parasuraman, A. and Malhorta, A.,(2000),"Conceptual Framework for Understanding E-Service Quality: Implications for Future Research and Managerial Practice", Report, Marketing Science Institute, Cambridge Massachusetts, No.115.

Zeithaml, V.A., Parsuraman, A., and Malhotra, A.,(2002), Service Quality Delivery Through Websites: A Critical Review of Extant Knowledge", Journal of The Academy of marketing science,Vol.30,No.4,pp.362-375.

Zeithaml, V.A.; Parasuraman, A. and Malhorta, A.,(2002), "Service Quality Delivery Through Websites: A Critical Review of Extent Knowledge, Journal of The Academy of Marketing Science, Vol.30,No.4,pp.362-375.

Zeithmal, V. A., Berry, L. L. and Parasuraman, A.,(1996),"The Behavioral Consequences of Service Quality", Journal of Marketing,Vol.60,pp.31-46.

Zeithmal, V. A., Parasuraman, A. and Malhotra, A.,(2000),"A Conceptual Framework for Understanding E-Service Quality: Implications for Future Research and Managerial Practice", Working Paper, Marketing Science

Institute, Cambridge, MA. 


\section{Appendix: Questionnaire items:}

\begin{tabular}{|c|c|}
\hline Variables and Sources & Items \\
\hline $\begin{array}{l}\text { Website's Ease of use } \\
\text { (Bressolles,et al.,2014) }\end{array}$ & $\begin{array}{l}\text { 1. The website which I deal with is easy to use(EOU1). } \\
\text { 2. It is easy to search for information and products through browsing the website which I } \\
\text { deal with(EOU2). } \\
\text { 3. It is easy to browse through the website which I deal with and access to information } \\
\text { and products that I search for(EOU3). } \\
\text { 4. The design of the website which I deal with makes it easy to search for information } \\
\text { and products (EOU4). }\end{array}$ \\
\hline $\begin{array}{l}\text { Website's information } \\
\text { (Bressolles and Durrieu, } \\
\text { 2010) }\end{array}$ & $\begin{array}{l}\text { 5. The website which I deal with provides accurate information about offered products } \\
\text { (WI1). } \\
6 \text {. The website which I deal with provides adequate information about offered products } \\
\text { (WI2). } \\
\text { 7. The website which I deal with provides recent information about offered products } \\
\text { (WI3). } \\
\text { 8. The website which I deal with provides detailed information about offered products } \\
\text { (WI4). } \\
\text { 9. The website which I deal with provides information related to offered products (WI5). }\end{array}$ \\
\hline $\begin{array}{l}\text { Website's reliability } \\
\text { (Bressolles, et al.,2015; } \\
\text { Cristobal, et al.,2007). }\end{array}$ & $\begin{array}{l}\text { 10. The website which I deal with provides information about the availability of offered } \\
\text { products' inventory (WR1). } \\
\text { 11. The website which I deal with provides information about alternative methods of } \\
\text { delivering sold products (WR2). } \\
\text { 12. The website which I deal with provides information about the timings of delivering } \\
\text { sold products (WR3). } \\
\text { 13. The website which I deal with keeps its promises offered to its customers (WR4). }\end{array}$ \\
\hline $\begin{array}{l}\text { Website's security } \\
\text { (Bressolles and Durrieu, } \\
2010 \text {; Bressolles, et al., } \\
\text { 2015) }\end{array}$ & $\begin{array}{l}\text { 14. I think that my personal information submitted to the website that I deal with are } \\
\text { secured and protected (WS1). } \\
\text { 15. I trust that the website which I deal with will not use my personal information for an } \\
\text { improper purpose (WS2). } \\
\text { 16. I trust the whole security of the website which I deal with (WS3). } \\
\text { 17. I trust that the website which I deal with will not misuse my personal information } \\
\text { (WS4). }\end{array}$ \\
\hline $\begin{array}{l}\text { E-customer satisfaction } \\
\text { (Oliver,1980;Ribbink } \\
\text {,et al., 2004). }\end{array}$ & $\begin{array}{l}\text { 18. I am happy because I buy products from the website that I deal with (ES1). } \\
\text { 19. In general, I am pleased with the services of the website which I deal with ( ES2). } \\
\text { 20. I am satisfied with the services of the website which I deal with (ES3). } \\
\text { 21. The website which I deal with is enjoying (ES4). }\end{array}$ \\
\hline $\begin{array}{l}\text { E-customer loyalty } \\
\text { Zeithmal,Berry and } \\
\text { parasuraman, } 1996\end{array}$ & $\begin{array}{l}\text { 22. I use a certain website (s) when I need to purchase a certain product (s) (EL1). } \\
\text { 23. When I need to purchase certain products, certain websites are considered my first } \\
\text { choice (EL2). } \\
\text { 24. I prefer certain websites for purchasing certain products (EL3). } \\
\text { 25. I believe that the website which I deal with is preferred for purchasing (EL4). }\end{array}$ \\
\hline
\end{tabular}

